\title{
A SURVEY OF LITERATURE REVIEW ON BANK PREFORMANCE
}

\author{
Nina Sinițîn \\ Doctoral School in Accounting, "1 Decembrie 1918" University of Alba lulia, Romania \\ ninasinitin@yahoo.ro
}

\begin{abstract}
This study analyses existing literature review studies on banking sector performance. Specially, this research aim is to identify topics of interest and development niche for this vast field. The paper presents a content analyses of 14 literature review on banking sector performance studies, selected using clear and transparency methodology. The content analysis of the papers identified that themes are diverse: banking performance and efficiency analysed using the DEA (Data Envelope Analysis) method, banking efficiency and risk, banking efficiency and competition, mobile banking and bank profitability. Based on selected papers this study identified that in recent years number of systematic literature revie studies increase, in the same time traditional literature review are decreasing.
\end{abstract}

Keywords: Bank; Performance; Literature review

JEL Classification: G21; L25

\section{Introduction}

The issue of banking performance is complex and delicate. In the context of severe competition and the presence of multiple risks, banking management has the responsibility of continuous analysis and ongoing assessment of behavior. Banking performance is a topic of great interest for the banking environment, extremely affected by the financial crisis. The banking environment, through its extrinsic financing function, in crisis situations played the role of shock receiver and stability provider for economic agents. The phenomenon of economic crisis has aroused the interest of researchers who have focused on studies on profitability analysis, influencing factors, as well as predictability models.

The purpose of this systematic literature review is to create a well-defined picture of existing studies in the field of banking performance. This research should answer the following questions:

$>$ Topics of interest in this vast field?

$>$ What are the data that formed the basis of the case studies of the research in the field?

$>$ What are the limits of research?

$>$ What are the questions, the hypotheses of the existing studies in correlation with the results?

Starting from these questions, we will develop a clear, transparent and reasoned methodology in search of studies relevant to our research.

\section{Search strategy used}

The first step of our research will be the search for studies of literature review in the field of banking performance in order to analyze and present existing studies, as well as their methodology. For this we used the platform Web of Science - Core Collection, InCites Journal Citation Reports, Derwent Innovations Index, Clarivate Analytics and we will do the search in English. This database allows an advanced search, so we searched all publications with the words: Bank next to Performance or Bank next to Profitability Bank next 
to efficiency and review or survey or going on with studies. Only publications in the field of social sciences, for period 2000-2020, were selected.

\section{Sample of studies}

Based on the search criteria specified above, we obtained a sample of 16 studies. Below we can see the detail of the sample of studies by years, as well as the number of citations related to the studies.

\section{Number of publications}

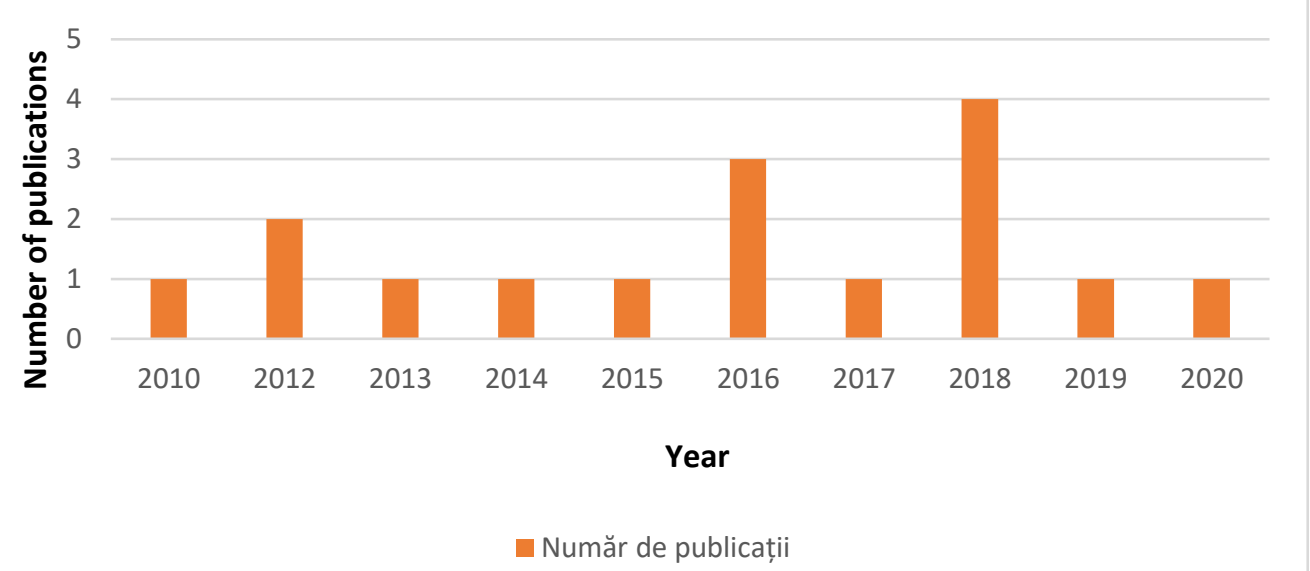

Figure 1: Number of publications presented per year

Source: prepared by the author

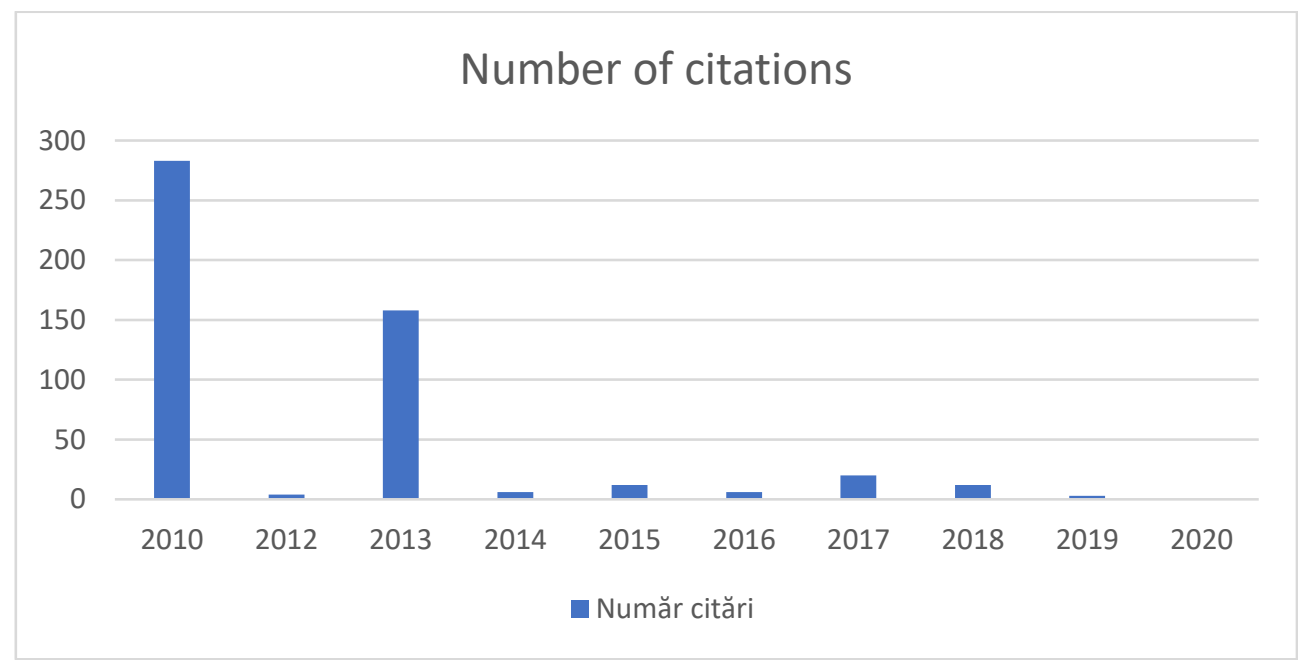

Figure 2: Number of citations of studied publications presented by years Source: prepared by the author

From the selected sample were excluded at the time of content analysis 2 studies: Oino, I. (2018) Sheikholeslami, M. \& Farkhodovich, O. F. (2012) due the fact that these studies are not a literature review study. 


\section{Types of review}

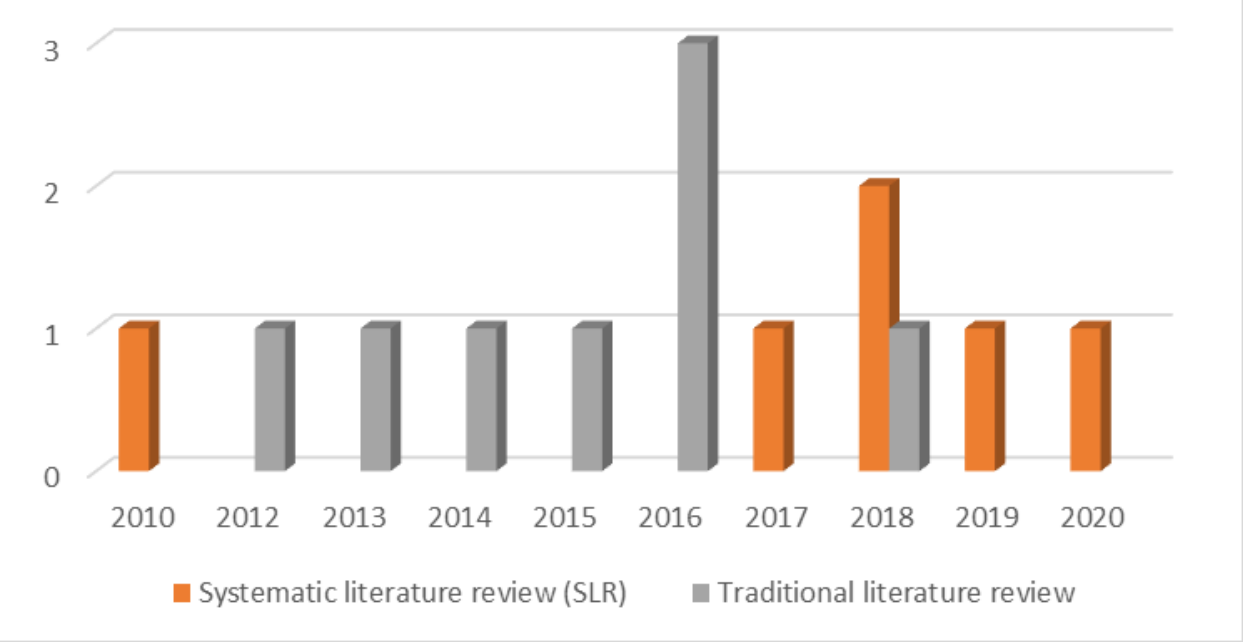

Figure 2: Types of literature reviews in analyzed sample

Source: prepared by the author

In the figure above, based on the studied works, we notice a smooth transition from the traditional literature review to the systematic literature review, in the last years 2017-2020 predominating studies based on the systematic literature review.

We must mention that our sample is a limited one due to the fact that we performed the search in a single database, but from our point of view it is a relevant one, presenting the various topics on which literature reviews were performed as well as the fact that presents the evolution of this concept from traditional to systematic. In none of the studied works is the literature on banking performance and accounting reviewed.

\section{Content Analysis}

4.

\begin{tabular}{|c|c|c|c|c|c|}
\hline Autor & $\begin{array}{l}\text { Article search } \\
\text { criteria, keywords }\end{array}$ & $\begin{array}{l}\text { Number } \\
\text { of } \\
\text { publicati } \\
\text { ons }\end{array}$ & Period & $\begin{array}{l}\text { Literature } \\
\text { review } \\
\text { type }\end{array}$ & Conclusions \\
\hline $\begin{array}{l}\text { (Ahmad et } \\
\text { al. 2020) }\end{array}$ & $\begin{array}{l}\text { Profitability, Effect } \\
\text { of Financial Ratio, } \\
\text { Capital adequacy } \\
\text { ratio (CAR), Non } \\
\text { performing loan } \\
\text { (NPL), Loan to } \\
\text { deposit ratio (LDR), } \\
\text { and Operating } \\
\text { income operating } \\
\text { costs (BOPO) }\end{array}$ & $\begin{array}{l}1996 \text { of } \\
\text { which } \\
100 \\
\text { analyzed } \\
\text { as } \\
\text { content }\end{array}$ & $\begin{array}{l}1985- \\
2018\end{array}$ & $\begin{array}{l}\text { Systematic } \\
\text { literature } \\
\text { review } \\
\text { (SLR) }\end{array}$ & $\begin{array}{l}\text { It presents a vast sample of specialized } \\
\text { works, based on clear selection criteria. } \\
\text { The analysis of the content of the first } \\
100 \text { works selected based on the number } \\
\text { of citations revealed five basic themes: } \\
\text { determinants, model and methods, } \\
\text { ownership, financial crises and } \\
\text { economies of scale. This study finds that } \\
\text { the Journal of Banking \& Finance is the } \\
\text { leading journal in terms of number of } \\
\text { publications and citations. The most } \\
\text { prolific author is Allen Berger based on } \\
\text { the dominance factor and the total } \\
\text { number of citations. And the paper with } \\
\text { the most citations is "Problem loans and } \\
\text { cost efficiency in commercial banks" by } \\
\text { Berger and DeYoung (1997). }\end{array}$ \\
\hline $\begin{array}{l}\text { (Andesfa } \\
\text { and }\end{array}$ & $\begin{array}{l}\text { Profitability, Effect } \\
\text { of Financial Ratio, }\end{array}$ & 26 & $\begin{array}{l}2000- \\
2017\end{array}$ & $\begin{array}{l}\text { Systematic } \\
\text { literature }\end{array}$ & $\begin{array}{l}\text { Based only on specialized studies, it is } \\
\text { concluded that the Capital Adequacy }\end{array}$ \\
\hline
\end{tabular}


The Annals of the University of Oradea. Economic Sciences

TOM XXX, $1^{\text {st }}$ Issue, July 2021

\begin{tabular}{|c|c|c|c|c|c|}
\hline Autor & $\begin{array}{l}\text { Article search } \\
\text { criteria, keywords }\end{array}$ & $\begin{array}{l}\text { Number } \\
\text { of } \\
\text { publicati } \\
\text { ons }\end{array}$ & Period & $\begin{array}{l}\text { Literature } \\
\text { review } \\
\text { type }\end{array}$ & Conclusions \\
\hline $\begin{array}{l}\text { Masdupi } \\
\text { 2018) }\end{array}$ & $\begin{array}{l}\text { Capital adequacy } \\
\text { ratio (CAR), Non } \\
\text { performing loan } \\
\text { (NPL), Loan to } \\
\text { deposit ratio (LDR), } \\
\text { and Operating } \\
\text { income operating } \\
\text { costs (BOPO) }\end{array}$ & & & $\begin{array}{l}\text { review } \\
\text { (SLR) }\end{array}$ & $\begin{array}{l}\text { Ratio (CAR) and the Loan to Deposit } \\
\text { Ratio (LDR) affect bank profitability. }\end{array}$ \\
\hline $\begin{array}{l}\text { (Banerjee } \\
\text { 2012) }\end{array}$ & Not specified & $\begin{array}{l}\text { Not } \\
\text { specified }\end{array}$ & $\begin{array}{l}\text { Not } \\
\text { specified }\end{array}$ & $\begin{array}{l}\text { Traditional } \\
\text { literature } \\
\text { review }\end{array}$ & $\begin{array}{l}\text { The paper examines transnational cross- } \\
\text { country studies on banking efficiency in } \\
\text { the new Member States of the European } \\
\text { Union (EU) and examines the relative } \\
\text { efficiency ratings of each country. } \\
\text { Different techniques and concepts of } \\
\text { efficiency give different results for } \\
\text { efficiency rankings, but some common } \\
\text { points are visible. The Czech banking } \\
\text { system is among the highest in terms of } \\
\text { technical efficiency and profit, but the } \\
\text { lowest in terms of cost efficiency. Banks } \\
\text { in Slovenia and Estonia are among the } \\
\text { most cost-effective. }\end{array}$ \\
\hline $\begin{array}{l}\text { (Bhatia et } \\
\text { al. 2018) }\end{array}$ & 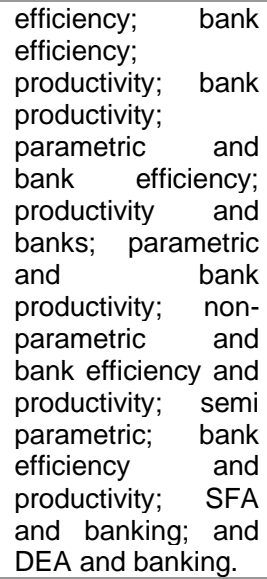 & 103 & $\begin{array}{l}1998- \\
2017\end{array}$ & $\begin{array}{l}\text { Systematic } \\
\text { literature } \\
\text { review } \\
\text { (SLR) }\end{array}$ & $\begin{array}{l}\text { This study presents a systematic review } \\
\text { of the literature in the context of bank } \\
\text { efficiency and productivity. The selected } \\
\text { research papers were coded according } \\
\text { to their key objectives and were } \\
\text { segregated into } 11 \text { themes: branch, } \\
\text { comparison, consolidation and } \\
\text { extension, banking regulation and } \\
\text { deregulation, environment, input-output, } \\
\text { methodological advances, non- } \\
\text { traditional activities. , risk, stock } \\
\text { performance and more. }\end{array}$ \\
\hline $\begin{array}{l}\text { (Dalwai, } \\
\text { Basiruddin, } \\
\text { and Rasid } \\
\text { 2015) }\end{array}$ & Not specified & $\begin{array}{l}\text { Not } \\
\text { specified }\end{array}$ & $\begin{array}{l}\text { Not } \\
\text { specified }\end{array}$ & $\begin{array}{l}\text { Traditional } \\
\text { literature } \\
\text { review }\end{array}$ & $\begin{array}{l}\text { The paper analyzes the different } \\
\text { empirical and theoretical contributions in } \\
\text { establishing the relationship between } \\
\text { corporate governance and banking } \\
\text { performance. }\end{array}$ \\
\hline $\begin{array}{l}\text { (de Abreu, } \\
\text { Kimura, } \\
\text { and } \\
\text { Sobreiro } \\
\text { 2019) }\end{array}$ & $\begin{array}{l}\text { Banking efficiency; } \\
\text { efficiency in } \\
\text { banking; technical } \\
\text { efficiency; bank }\end{array}$ & 87 & $\begin{array}{l}2011- \\
2017\end{array}$ & $\begin{array}{l}\text { Systematic } \\
\text { literature } \\
\text { review. }\end{array}$ & $\begin{array}{l}\text { Analyzes and presents current research } \\
\text { on banking efficiency in major finance } \\
\text { journals. Classify studies based on study } \\
\text { type, approach, objectives and } \\
\text { methodology. Applying Lotka's law } \\
\text { determines that the field of banking } \\
\text { efficiency has a low productivity, not } \\
\text { having a significant number of prolific } \\
\text { authors or specialized institutions. }\end{array}$ \\
\hline $\begin{array}{l}\text { (Fernandes } \\
\text { et al. 2018) }\end{array}$ & Not specified & $\begin{array}{l}\text { Not } \\
\text { specified }\end{array}$ & $\begin{array}{l}\text { Not } \\
\text { specified }\end{array}$ & $\begin{array}{l}\text { Traditional } \\
\text { literature } \\
\text { review }\end{array}$ & $\begin{array}{l}\text { It presents a review of the theoretical and } \\
\text { empirical literature on the relationship } \\
\text { between corporate governance and } \\
\text { banking performance, providing a } \\
\text { comprehensive understanding of existing } \\
\text { research. It also touches on the issue of }\end{array}$ \\
\hline
\end{tabular}


The Annals of the University of Oradea. Economic Sciences

TOM XXX, $1^{\text {st }}$ Issue, July 2021

\begin{tabular}{|c|c|c|c|c|c|}
\hline Autor & $\begin{array}{l}\text { Article search } \\
\text { criteria, keywords }\end{array}$ & $\begin{array}{l}\text { Number } \\
\text { of } \\
\text { publicati } \\
\text { ons }\end{array}$ & Period & $\begin{array}{l}\text { Literature } \\
\text { review } \\
\text { type }\end{array}$ & Conclusions \\
\hline & & & & & $\begin{array}{l}\text { the board and its impact on banking } \\
\text { performance. }\end{array}$ \\
\hline $\begin{array}{l}\text { (Fethi and } \\
\text { Pasiouras } \\
\text { 2010) }\end{array}$ & 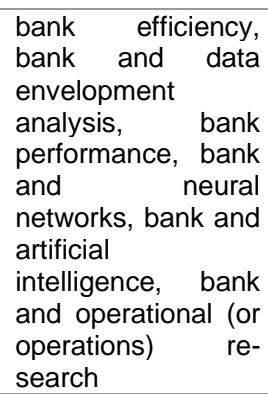 & 196 & $\begin{array}{l}1998- \\
2009\end{array}$ & $\begin{array}{l}\text { Systematic } \\
\text { literature } \\
\text { review. }\end{array}$ & $\begin{array}{l}\text { This study presents a comprehensive } \\
\text { review of } 196 \text { studies using operational } \\
\text { research techniques (O.R.) and artificial } \\
\text { intelligence techniques (A.I.) in } \\
\text { assessing banking performance. }\end{array}$ \\
\hline (Jia 2016) & Not specified & 20 & $\begin{array}{l}\text { Not } \\
\text { specified }\end{array}$ & $\begin{array}{l}\text { Traditional } \\
\text { literature } \\
\text { review }\end{array}$ & $\begin{array}{l}\text { This study examines twenty research } \\
\text { articles on banking efficiency in China. }\end{array}$ \\
\hline $\begin{array}{l}\text { (Kumar } \\
\text { and Gulati } \\
2014 \text { ) }\end{array}$ & Not specified & $\begin{array}{l}\text { Not } \\
\text { specified }\end{array}$ & $\begin{array}{l}\text { Not } \\
\text { specified }\end{array}$ & $\begin{array}{l}\text { Traditional } \\
\text { literature } \\
\text { review }\end{array}$ & $\begin{array}{l}\text { This chapter presents a survey of the } \\
\text { empirical literature on bank efficiency. It } \\
\text { is concluded that the bank's efficiency } \\
\text { score may differ completely due to the } \\
\text { measurement technique and there is } \\
\text { virtually no consensus on the preferred } \\
\text { method of estimating the bank's } \\
\text { efficiency. }\end{array}$ \\
\hline $\begin{array}{l}\text { (Paradi and } \\
\text { Zhu 2013) }\end{array}$ & Not specified & 80 & Din 1985 & $\begin{array}{l}\text { Traditional } \\
\text { literature } \\
\text { review }\end{array}$ & $\begin{array}{l}\text { This study analyzes } 80 \text { researches on } \\
\text { banking performance and efficiency } \\
\text { analyzed using the DEA (data envelope } \\
\text { analysis) method published in } 24 \\
\text { countries / areas that focus mainly on } \\
\text { bank branches. }\end{array}$ \\
\hline $\begin{array}{l}\text { (Tam and } \\
\text { Oliviera } \\
2017 \text { ) }\end{array}$ & $\begin{array}{l}\text { mobile banking; } \mathrm{m} \text { - } \\
\text { banking }\end{array}$ & 64 & $\begin{array}{l}2002- \\
2016\end{array}$ & $\begin{array}{l}\text { Systematic } \\
\text { literature } \\
\text { review } \\
\text { (SLR) }\end{array}$ & $\begin{array}{l}\text { Analyzes and presents studies on } \\
\text { mobile-banking and banking } \\
\text { performance. The obtained results } \\
\text { indicate that the subject of mobile- } \\
\text { banking implementation and behavioral } \\
\text { intent dominate most research, but we } \\
\text { find very few studies on post- } \\
\text { implementation. }\end{array}$ \\
\hline $\begin{array}{l}\text { (Tan } \\
2016 b)\end{array}$ & Not specified & $\begin{array}{l}\text { Not } \\
\text { specified }\end{array}$ & $\begin{array}{l}\text { Not } \\
\text { specified }\end{array}$ & $\begin{array}{l}\text { Traditional } \\
\text { literature } \\
\text { review }\end{array}$ & $\begin{array}{l}\text { This chapter mainly reviews the empirical } \\
\text { literature on banking efficiency and } \\
\text { competition. Study the two aspects at the } \\
\text { international level, then limiting yourself } \\
\text { to one country - China. Finally, this } \\
\text { chapter examines relevant theories and } \\
\text { studies on the impact of competition on } \\
\text { banking efficiency. }\end{array}$ \\
\hline $\begin{array}{l}\text { (Tan } \\
2016 a)\end{array}$ & Not specified & $\begin{array}{l}\text { Not } \\
\text { specified }\end{array}$ & $\begin{array}{l}\text { Not } \\
\text { specified }\end{array}$ & $\begin{array}{l}\text { Traditional } \\
\text { literature } \\
\text { review }\end{array}$ & $\begin{array}{l}\text { This chapter studies the literature on } \\
\text { banking efficiency and risk, presenting } \\
\text { relevant aspects for each of these } 2 \\
\text { areas as well as the close connection } \\
\text { between them. }\end{array}$ \\
\hline
\end{tabular}

Table no. 1 Analysis of the review works of the specialized literature on bank profitability.

Source: prepared by the author

According to the table above, we notice that most of the studied works present a traditional literature review, and it does not present clear criteria regarding the selection criteria of the analyzed literature. At the same time we notice that in recent years number of systematic literature revie studies increase, in the same time traditional literature review are decreasing. 
The topics on which these empirical studies were conducted are diverse: banking performance and efficiency analyzed using the DEA (Data Envelope Analysis) method, banking efficiency and risk, banking efficiency and competition, mobile banking and bank profitability. Many of the studies analyzed refer to the banking system from China.

Analyzing the existing literature review on bank performance topic, it is surprising that none of the papers address the topic of accounting and bank performance.

\section{Conclusions}

The purpose of this study is to create a well-defined picture of existing studies in the field of banking performance. Analyzing sample of selected studies, we identified that the topics for existing literature review studies are diverse: banking performance and efficiency analyzed using the DEA method, banking efficiency and risk, banking efficiency and competition, mobile banking and bank profitability. Most of the studies refer to the banking system from China. We must mention that our sample is a limited one due to the fact that we performed the search in a single database, but from our point of view it is a relevant one, presenting the various topics on which literature reviews were performed as well as the fact that presents the evolution of this concept from traditional to systematic. In none of the studied works is the literature on banking performance and accounting reviewed.

\section{Acknowledgements}

This work is supported by project POCU 125040, entitled Development of the tertiary university education to support the economic growth - PROGRESSIO, co-financed by the European Social Fund under the Human Capital Operational Program 2014-2020

\section{References}

1. de Abreu, Emmanuel Sousa, Herbert Kimura, and Vinicius Amorim Sobreiro. 2019. "What Is Going on with Studies on Banking Efficiency?" Research in International Business and Finance 47: 195-219. https://doi.org/10.1016/j.ribaf.2018.07.010.

2. Ahmad, Nisar, Amjad Naveed, Shabbir Ahmad, and Irfan Butt. 2020. "BANKING SECTOR PERFORMANCE, PROFITABILITY, AND EFFICIENCY: A CITATION-BASED SYSTEMATIC LITERATURE REVIEW." Journal of Economic Surveys 34(1): 185-218.

3.Andesfa, Debby, and Erni Masdupi. 2018. "Effect of Financial Ratio on Profitability of Comercial Banks: A Systematic Literature Review." Advances in Economics, Business and Management Research 64: 700-706.

4.Banerjee, Biswajit. 2012. "Banking Sector Efficiency in New EU Member States. A Survey of CrossCountry Evidence." Eastern European Economics 50(6): 81-115.

5.Bhatia, Vaneet, Sankarshan Basu, Subrata Kumar Mitra, and Pradyumna Dash. 2018. "A Review of Bank Efficiency and Productivity." Opsearch 55(3-4): 557-600. https://doi.org/10.1007/s12597-0180332-2.

6.Dalwai, Tamanna Abdul Rahman, Rohaida Basiruddin, and Siti Zaleha Abdul Rasid. 2015. "A Critical Review of Relationship between Corporate Governance and Firm Performance: GCC Banking Sector Perspective." Corporate Governance (Bingley) 15(1): 18-30.

7.Fernandes, Catarina, Jorge Farinha, Francisco Vitorino Martins, and Cesario Mateus. 2018. "Bank Governance and Performance: A Survey of the Literature." Journal of Banking Regulation 19(3): 23656.

8.Fethi, Meryem Duygun, and Fotios Pasiouras. 2010. "Assessing Bank Efficiency and Performance with Operational Research and Artificial Intelligence Techniques: A Survey." European Journal of Operational 189-98. http://www.sciencedirect.com/science/article/pii/S0377221709005438. 
9.Jia, Jingyi. 2016. "Efficiency of Chinese Banks: A Survey and Suggested Directions for Future Research." Chinese Economy 49(4): 239-56.

10.Kumar, Sunil, and Rachita Gulati. 2014. A Survey of Empirical Literature on Bank Efficiency.

11.Paradi, Joseph C., and Haiyan Zhu. 2013. "A Survey on Bank Branch Efficiency and Performance Research with Data Envelopment Analysis." Omega (United Kingdom) 41(1): 61-79. http://dx.doi.org/10.1016/j.omega.2011.08.010.

12.Tam, Carlos, and Tiago Oliviera. 2017. "Literature Review of Mobile Banking and Individual Performance Abstract." International Journal of Bank Marketing 35(7): 1042-65.

13.Tan, Yong. 2016a. "Literature Review on Bank Effi Ciency and Bank Risk." In Investigating the Performance of Chinese Banks: Efficiency and Risk Features, , 79-104.

14._. 2016b. "Literature Review on Bank Efficiency and Bank Competition." In Efficiency and Competition in Chinese Banking. 1-183. 